\title{
ATHLETE'S LIFE PATH IN THE PERSPECTIVE OF GENDER ATHLETES REPORTING OPPORTUNITIES IN THEIR SPORTS AFTER THEIR SPORT CARRIER
}

\author{
Piroska Béki ${ }^{1}$, Beatrix Faragó ${ }^{2}$ \\ ${ }^{1}$ Eszterházy Károly University, Eger \\ ${ }^{2}$ Széchenyi István University, Győr \\ 1piroka.beki@gmail.com \\ ²farago.beatrix@sze.hu
}

\begin{abstract}
Sport is the highlight of the male-female relationship system. We find that the concept of homogeneity is becoming more and more weakened, sport becomes unisex, which can strongly influence gender judgment in society. The "weaker sex" appearance and spread of the sport indicate that something has changed in the world, so thinking has to change also. Nowadays, there is a dual process in the field of sport: 1.) women appear in the traditionally masculine sports, and this plays an important role in the development of gender relations as mixed races arise; 2.) at the same time, men also appear in previously reserved areas for women, which they have not had opportunities so far (BÉKI, 2018). This phenomenon can be observed, though much slower in sports management. Yet in other sports roles, the gates for both sexes have not yet been opened in masculine and feminine sports. The study deals with how the status of an athlete will be transformed after sport if he/she wants to remain his or her sport in other sports roles - concentrating on coaching and judging roles - to represent his or her own sport. Particularly, we have been focusing on sports whose judgment is not socially acceptable to both sexes. The research sample is team and individual women athletes who are more than 14 years old. Research method is in-depth interview research $(n=145)$ and questionnaire research $(n=240)$. The results showed that female athletes are becoming more accepted in masculine sports, although more limited in their careers possibilities than men after an athlete's life. Their athlete's identity is strong, they want to stay in the sport on the civilian life as well.
\end{abstract}

Keywords: feminine-masculine sport, carrier opportunities, other sports role, dual career (JEL code: $J 71$ )

\section{INTRODUCTION}

For a long time, the only intellectual career open to women was the teacher. Women were excluded from civil rights, the military, and even university-level studies. There was only one possible way to break out, and that was to try to "become men" and adapt to the "masculine" profession. The relationship between men's position of power and the division of labor plays a major role in determining the most common inequalities. The oppressive dominance of men has persisted in modern societies, so it is the task of women to fight for equality (ANDORKA, 2006). The place (limited) appearance of women in the division of labor in men's professions less reflects the change in the situation of women, as women's career development commitment is severely limited, "suppressed" by the existence of the so-called occupational "glass ceiling" (DABASI HALÁSZ, 2011; FEKETE and SIPOSNÉ NÁDORI, 2013). The woman from the earliest period in history has been involved in the system of division of labor, mainly in the field of work around the household (PETŐ, 2017). The emergence of women in sport has made it clear that they want to "fight" with men in a new field: 
challenging previous beliefs and stereotypical perceptions about the measurability of performance (BÉKI, 2017). Although we are already approaching equal participation rates for women and men in sports (olimpic.org) - this is shown by the nearly 50-50 percent participation rate at the Rio Olympics - but in sports that are not acceptable to the opposite sex (e.g. female boxing, men's swimming) there is no possibility to advance in other sports roles after elite sports. As traditional gender roles weaken or disappear, women are increasingly able to penetrate various sports. Despite the increasing help of women and sports on the American continent, for example, the IX. by 1972, U.S. law prohibits discrimination based on gender in any federally funded educational program or activity - there is still untapped territory (BÉKI and GÉCZI, 2017). The literature on the subject focuses most of the changes in the 21st century on the process that deals with women's legal capacity. Modernization has been widely accompanied by the recognition of women's legal capacity and the progressive guarantee of their equal rights. Their position in the labor market has changed, because they have broken out of the role of housewives and have started working alongside their families, moreover, they are also pursuing a career by taking on the increasingly fashionable singles. Several areas of public life, politics, and culture were opened up to them. The situation of women has also changed with the change in the division of labor. Women already appeared on the labor market (GŐSI and SALLÓI, 2017) at the time of the Industrial Revolution, although at that time they were only able to infiltrate unskilled auxiliary jobs (SOMLAI, 1997). Sports is a masculine field, especially in Hungary, where we encounter many gender conflicts. In addition, former professional athletes facing difficulties in the aftermath of the sport have to struggle to survive in other areas of life, treat them differently in other settings, and therefore face a sense of 'fall'. This is especially true for sports where society defines the accepted dominant gender associated with the sport. Sport is also a key strategic sector in Hungary (BÁCSNÉ BÁBA et al, 2019). The athlete will also appear in the job market and an employee with sports competencies can be employed more effectively. Although the competencies that appear in sports are not exactly the same, as the teamwork skills of the representatives of team sports and individual sports are different, the basic competencies related to sports are the same. These advanced competencies and the need for lifelong learning are now essential for successful career choices (RÁTHONYI-ODOR et al, 2013). Thus, it can also be applied to the athlete segment as a labor market base that new systems are being built with the spread of globalization and the knowledge-based economy, and new expectations are emerging. It needs to think, meet, and develop the market resources on an international level (FARAGÓ, KONCZOSNÉ SZOMBATHELYI 2017). Although the physiological parameters of women athletes differ from men, they appear equally in athlete performance. The mental and physical fitness and endurance of female athletes rival that of men. (SZAKÁLY et al, 2003) Two problems are raised, which are also based on personal experience and on literature.
On the one hand, coping is a complex and time-consuming process, requires constant preparation to assess the gender of athletes, coaches, and sports leaders, and on the other hand, elite athletes have quite limited opportunities after completing their sporting careers, placement in their own sports or other areas.

\section{WOMEN IN SOCIETY}

\section{"Gender relations are hierarchical at the societal level" (BELINSZKI, 2003)}

The lifestyle of women in most societies was determined by family functions, while men appear mostly in social activities such as earning money, subsistence, work. Women are responsible for the care of the spouse and the upbringing of the child. The male role is manifested in the interaction with the woman (BUDA, 1998). According to an article published in the 2016 index, there were female samurai even in traditional Japan (index.hu). The topic is interesting because the knowledge of swordsmanship and fighting was masculine in this culture as well, but in a slightly different way, as protecting the family, the home was a female task that even had to be protected with a sword. In Japan, women also understood traditional swordsmanship before the advent of samurai. After these, the 17-18. in the twentieth century, women were marginalized from politics, struggle, and public life, and men saw women as tools, "parent machines". Although after World War II, Japanese women were given the same rights as men, from 1946 onwards they could vote. ABELE (2000) researched which gender role-oriented women or men are more prevalent in the labor market after graduating from university. His results showed that those with a masculine or androgynous character were more likely to get a job that matched their education, while those with a feminine or indifferent gender role orientation either did not find it at all or could only find a job well below their qualifications. As the issue of gender versus sexual difference has become widely debated, feminists have insisted that gender is not simply a matter of sexual difference but a matter of power (sexual hierarchy) "since we have looked at history from a gender perspective, we have found sexual asymmetry in every known society, inequality and male dominance "(SHOWALTER, 1989) Throughout history, as now, the issue of power has seemed most central to the relationship between men and women (PARRATT, 1989). Female historians have recognized the fact that the relationship between the sexes is much more determined by society than by nature. The strategy of studying the historical history of women and men using different systems of perspectives that have been shown to be particularly useful in bringing the world of women's history into the world of analytical social history has also been questioned in its attempt to emphasize difference rather than explain reciprocity between gender and society (KERBETH, 1988). In the study of Nancy STRUNA, Gender and Sporting Practice in Early America (1991) emphasized the diversity of women's experiences and the ever-changing nature of 
gender relations. Urban women, women farmers, slaves, white servants, women in villages and at the border, all have very different opportunities to build their own forms of recreation as well as different relationships with men.

According to the legal institution of "boyhood", in the old case law, if there was no son's offspring in the family, he died early or unexpectedly, the family had the right to marry the girls so that they could inherit the family property. In a boy's family, the girls did not inherit, they received nothing but their dowry, the purpose of this rigor was to prevent the fragmentation of the family estate.

That is, if necessary, they were able to disregard the biological gender and assert their interests in the social gender (in farrowing, the interests of the wealthy family so that wealth did not fall back on the crown.).

The need for equality appears in education, see Blanka Teleki and her circle, who fought for the equal education of women with men (1870s).

This was followed by the struggle for the right to vote and all the other stations of the struggle for equality.

The social and symbolic structure of gender differences has shown that the language of gender differences has provided a means of articulating power relations (VERTINSKY, 1983). Feminism has found itself confronted with the need to articulate the woman herself: "they have no past, no history, no religion of their own, lack the solidarity at work and the protection of interests that the proletariat has" (OFFEN, 2000). According to WALBY's 1996 theory, men's pay is higher than women's, even if the position is the same, and it is also typical that women are more likely to win lowerpaid jobs. In other areas, men are involved in a very small proportion of domestic work, which he describes as largely a female task. It supports this theory. In Hungary, NAGY (1993) showed that there are significantly fewer female executives in terms of intellectual occupations. The results of the research clearly show that the proportion of women in senior positions has increased almost 6 times since the change of regime in 1960 , but is still far behind the number of men. In addition, HADAS's (1994) research findings indicated that men fill jobs that involve power and require virtue alongside them, while women prefer those with subordination. According to a 1998 study by NEMÉNYI and TÓTH, women are the losers of the 1990 regime change. Their claim was based on an examination of the proportion of women and men in the labor market. In their view, these roles vary from society to society, but "feminism is about serving the interests and desires of men". ANDORKA (2006) came to similar results. Men perform occupations involving power, while women appear in subordinate areas that require softness. HADAS (1994) also examined music sessions. His results show that conducting is typically masculine, while women are more successful among strings, wind instruments, harpists, and singers. There is a very close connection between the division of labor and sport. As traditional gender roles weaken or disappear, women are increasingly able to penetrate various sports. Despite the increasing help of women and sports in the Americas, for example, the IX. by law, since 1972,
U.S. law prohibits discrimination based on gender in any federally funded educational program or activity - there is still untapped territory (BÉKI and GÉCZI, 2017).

\section{GENDER PERCEPTIONS IN SPORT}

Many studies have been written on the topic of gender and sport in the history of the Olympics, of which about women will it present in this chapter. There are stories and reports about the marginalization of women in sports or the possibility of promotion or appearance on the ranks of the International Olympic Committee. They also provide information on the exclusion of women from sports opportunities in old and modern games. In other cases, we can read the story of the trials and tribulations of Olympic heroes and heroines. The relationship between women and the Olympic Games is a topic that can be approached from many angles. To achieve this goal, athletes and individual nations are able to cross boundaries such as the start of male competitors between women (GÁL and FARKAS, 2016), which ended with the introduction of sex testing (BÉKI, 2015). At the same time, the central role of sport should not be overlooked, which is based on gender, class/origin, and sexuality-based encirclement of power (EITZEN, 1996). Women and girls have the right to play sports and take advantage of sources of physical activity and other opportunities. (LENSKYJ, 2005). In Western countries, focusing on the theme of gender, an universal "woman" has been invented who deserves equal sports opportunities. With regard to competitive sports, for decades the emphasis has been on making more sports and sporting events viable for women, unbiased coverage, greater financial security, more support, more advanced career opportunities, better training, and others while organizing international sports competitions which peak of the Olympics remains intact (BÉKI, 2018). In his study, BODNÁR (2003) explained that the role perception of male identity in relation to sport needs to be transformed. In today's modern societies, including Hungary, the roles of women and men are merging both in the labor market and in other fields, including sports. In his doctoral dissertation, BODNÁR (2012) mostly examined coaching competencies and the acceptance of women in this field. In contrast to men's martial arts, the exercises recommended for women cannot be identified with competitive sports because it requires traits that women do not have. Sports recommended for women can be characterized as permeated with aesthetics, pleasure and body experience. It is difficult to ignore the persistent inequality between men's and women's opportunities to compete in the sport they choose (e.g., martial arts) and the ever-present stereotypes about which sports are appropriate and inappropriate for women. Metheny's theory (1965) examined the social acceptance of sports, in which she showed what is accepted and what is not for women. They divided the sports into three groups according to their characteristics. The first group included those whose pursuit was not ac- 
cepted, the second those that were neutral, and the third those that were perfectly appropriate for women. He also divided the groups into subcategories with explanations. First, it does not recommend sports in which direct physical contact appears between opponents. These include handball, football, martial arts, etc. Secondly, it does not consider acceptable areas where heavy objects need to be moved or the force of the body is being used heavily. These sports include weightlifting. Thirdly, long-term continuous exercise, which is not recommended for marathon runners, cross-country skiers, etc., is not recommended. displayed. The neutral category includes sports where the weight of the object being moved is medium, does not require more effort, and sports where physical contact between opponents is prohibited, thus leaving less space among athletes (basketball). The specifically feminine category includes those where the weight of the sports equipment is light, small (javelin throw, tennis, etc.), or provides an aesthetic experience for the viewer (rhythmic gymnastics, synchronized swimming, etc.). In two other categories, he defined sports in which physical contact is impossible, as a net separates opponents (badminton, volleyball, tennis, etc.) and those that require joint mobility and flexibility (high jump, etc.). BÉKI (2018) examined which Olympic sports in Hungary could be the focus of research based on Metheny's system. Based on the answers of sports professionals, the Hungarian sports classification was outlined (Table 1). Thus, the focus of the present study was to compare the masculine and feminine sports in Table 1 with those of Metheny's previous groups.

Table 1: Judging sports (Béki, 2018)

\begin{tabular}{lll}
\hline & Value & Sports \\
\hline Feminine & $1-2$ & $\begin{array}{l}\text { figure skating, rhytmic gymnastics, } \\
\text { synchronised swimming }\end{array}$ \\
\hline Masculine & $4-5$ & $\begin{array}{l}\text { wrestling, judo, boxing, weightlifting, football, } \\
\text { ice hockey, heavy field athletics }\end{array}$ \\
\hline & & $\begin{array}{l}\text { water polo, volleyball, handball, basketball, } \\
\text { taekwondo, canoe, kayak, marathon running, } \\
\text { pole vault, cycling, speed skating, rowing, } \\
\text { cross-country skiing, biathlon, track and field, } \\
\text { table tennis, tennis, badminton, gymnastics, } \\
\text { triathlon, swimming, fencing, sailing, surfing, } \\
\text { diving, equestrian, sprint, field hockey, archery, } \\
\text { shooting modern pentathlon, bobsleigh, curling, } \\
\text { luge, snowboarding, ski jumping }\end{array}$ \\
\hline
\end{tabular}

\section{ATHLETE CAREER OPPORTUNITIES}

"Abuses of power are fueled by the hunger for success, the role of life-and-death coaches should be redefined, and they should rebuild their relationship with the competitors.

To do this, however, is more educated, more empathetic, and not masters from ex-champions would be needed."

(BUDAVARY, 2018)
The most topical and most mentioned topic is the issue of the dual career of athletes. In this topic, we can see the results of several famous researchers (FARKAS, 2012; STERBENZ et al., 2017; ANDRÁS, HAVRAN, 2017) in different sports. Interestingly, they ponder the chances of finding a job in the job market but don't specifically address the return to sports after racing. The European Union also draws up guidelines on the subject, entitled "EU Guidelines on Dual Careers of Athletes", which was published in 2012 and also does not deal with the subject separately. There are also programs in Hungary that specifically help the life paths of elite athletes. The MOB Olympic Lifestyle and EMMI Sports Stars Scholarship Program offers many opportunities, although it does not help you return to your own sport. The issue of the dual career of athletes is a well-known topic throughout Europe, but Hungary still has little good practice. The range of beneficiaries of the two support programs operating in Hungary is narrow, as it only supports athletes studying in higher education who have a chance to win medals during their studies (FARKAS et al., 2017). Several literatures deal with the aspects of pedagogy and sports similarly (GOMBOCZ 1998, RÉVÉSZ et al., 2007, GOMBOCZ and GOMBOCZ 2008, RÉVÉSZ, et al., 2013). For example, one of the key goals of starting compulsory school physical education is the contribution of sport to the development of young people (BODNÁR and PERÉNYI, 2016). The career path of a top athlete is very different from the traditional one. A person in a civilian profession spends 12-17 years at a desk and then, after completing his or her studies, enters the labor market where he or she works until retirement. In contrast, the elite athlete also begins his career at the start of elementary school. This leaves them with less time to learn. With regard to dual careers, two areas need to be mentioned, one is education, the other is entering the labor market. Both conceal ongoing conflicts (KISS, 2017). An individual's career choice is a multi-year decision-making process that is influenced by the specific labor market background, family's career orientation, parents' occupation, the highest level of education, teachers, classmates, and friends, ie the medium from which the individual comes out (RÁMHÁP, 2017). Those with higher education are more likely to enter the labor market and are in a better position (SOMLAI, 2010). Several previous researches have revealed (GfK, 2015; Deloitte, 2015) that high school and higher education students do not have a realistic career picture. They generally predict a higher level of their expected income or job prospects. Civil careers after elite sports can take different directions. Successful athletes took the barriers to complete the sport more easily than their less successful counterparts. Education also influenced their opportunities, as they were able to find more employment in the labor market, thus facing fewer employment difficulties in their later lives (MURPHY et al., 1996; WILLIAMS and RYCE, 1996). Often, elite athletes focus all their energy on achieving sports results, so in civilian 
life, they often let go of their hands and step out of the vacuum (FARAGÓ et al., 2018). The importance of nonsport careers needs to be highlighted on time, in which parents, coaches, teachers, and sports associations also play an important role (FARAGÓ, 2015). "Another problem with choosing a sports career in youth is that many athletes who are considered talented in youth do not reach a level where sport provides them with a livelihood. After graduating from school, they have to enter the world of work instead of a sports career. That is why organisations and professional dealing with youth education must pay attention to maintaining the balance between sports and learning "(GŐSI and SALLÓI, 2017). GŐSI's 2018 study shows one of the possible career building of elite athletes, namely the future of his own sport in other sports roles, such as coaching sports manager or sports reporter. FARAGÓ and KONCZOSNÉ SZOMBATHELYI research (2017) examined exactly what professional plans athletes report after their sports careers. Typically, their interviewees plan to return to the sport regardless of the sport, and want to develop professionally in this area. On the one hand, the result is significant, according to which they want to continue their professional studies in sports and continue to work in sports (11.3\%), the other big area was starting their own sports business $(8.1 \%)$ or sports club (4.8\%) want to establish.

\section{MATERIALS AND METHODS}

With the literature, we examined a specific area in this study. We were curious about the chances of a former elite athlete in Hungary, in this cultural environment, to find a job in the labor market or return to his sport. Our goal was to present the labor market, as well as refereeing and coaching opportunities in sports that society finds undesirable for men or even women. Thus, joining additional sports roles is not an easy task for a former female or male competitor. During the interviews, we tried to ensure neutral conditions for direct conversation. We chose a semi-structured format in which both closed and open questions were used. The latter allows the respondent to express his or her own opinion. In the semistructured form of an interview, a particular problem is the focus of the questions and not just the person of the respondent (HÉRA and LIGETI 2005). We recorded the interviews personally: by sport, in case of a large number of people in groups, in case of a smaller number of people individually. In the course of our research, we used the semi-structured in-depth interview to explore the subjective opinion of elite athletes. The research examined female athletes with a questionnaire survey about their preparation for a dual career, its conscious preparations, and how much they are attached to the sport on the civilian track. We elaborated on the part of the in-depth interview questions that we asked all of our interviewees to have a chance to compare. Spontaneous questions raised during the conversations formed the other part of the in- terviews. Interviews with female athletes were recorded on a dictaphone with the consent of the interviewees. The interviews took place at pre-arranged times, in calm conditions, in most cases in a separate room. The duration of the interviews ranged from 20 to 60 minutes per person. Thus, female competitors in the following sports were included in the sample:

Team sports: Handball: 9 people, Volleyball: 6 people, Water polo: 12 people, Football: 21 people, Hockey: 23 people.

Individual sports: Rhythmic gymnastics: 7 people, Boxing: 15 people, Weightlifting, weightlifting: 6 people, Judo: 6 people, Wrestling: 6 people, Weightlifting: 4 people, Synchronized swimming: 3 people, Figure skating: 7 people.

In the interviews, we examined the roles of coaches and referees in terms of the experiences that elite athletes have so far with potential judges or coaches of the same sex and what opportunities they see in their own sport. In the questionnaire research, the sample represented women who played sports or played sports in a sports association over the age of 14 , the number of sample was $240(\mathrm{~N}=240)$. The questionnaires were completed at a time and in a manner agreed in advance with the sports associations, some on the online interface and some based on a personal request. The results were analyzed with SPSS statistical software. We have three hypotheses in the research.

- H1: Based on the literature, we assumed that female athletes in masculine and male athletes in feminine sports do not have the opportunity to return to other sports roles at the end of their athletic careers (coach, judge).

- H2: Furthermore, we assumed that athletes in these sports would be more accepting of coaches of the opposite sex, yet these roles were among their own career opportunities.

- H3: Based on athlete identity, female athletes want to stay in the sport during their civilian careers as well.

\section{RESULTS}

According to the results of the questionnaire, handball is not one of the men's sports in Hungary, yet it is included in the 1965 classification. Our respondents also find it all a rough sport, yet they believe that women's participation is accepted, which is explained by the effectiveness. 50 years and the results can change the perception of a women's discipline, and even a judicial career is an accepted women's career in the sport. However, none of my interviewees reported having had a female coach before. Interestingly, 2 athletes 'future plans, however, included a coaching career in handball. 
"I can't imagine my coach being a woman."

A handball woman said, and later in the interview, she has a contradictory view of her own career goals:

\section{"I want to learn more and I want to be a handball coach."}

An interesting result for us is the judgment of the female profession of water polo. While water polo women, like handball players, are considered masculine, the sport itself is considered neutral despite physical contact. The women playing for the national team similarly explain this with their effectiveness, and like handball, we only meet female referees in Hungary for the time being. Although the women's field of water polo is much younger, the assessment of both in Hungary is gender-neutral, the opportunities for female competitors to return are yet to come. Among women playing water polo, a coaching career is not a tempting career option, but they are planning to continue their education without exception, or are already beyond graduating from college.

\section{"I don't think there is a chance as a woman in wa- ter polo today as a coach." (Water polo woman)}

The case of volleyball is just the opposite. It is an accepted sport for women in Metheny's system. Athlete women are pretty, which they also try to emphasize on the track with their sportswear. Both coaching and refereeing careers are open to both sexes, as in practice both genders appear in both roles. It is no wonder, then, that the respondents consider this team sport to be neutral as well, so in this case, too, their perception has changed compared to the previous 1965 classification. The coaching career choice is also planned by the female athletes, they consider it a good opportunity to stay in their sport in the field of later career choice.

\section{"My role model is my coach and he is a woman" (Volleyball woman)}

Hockey and football could not get rid of the traditionally masculine origins even after 50 years, despite the fact that women in football are successful. In both sports, it is typical that female coaches have not yet appeared on the labor market and that women athletes do not plan to represent their sport as coaches in the future. Women footballers are mostly looking for career opportunities abroad in other fields, hockey players are similarly planning their future in other professions in Hungary. However, the presence of female referees can already be observed in football, even in hockey this is not typical, but even in this field, the presence of women is not accepted. Unfortunately, also due to the youth of the women's field of hockey, it lags far behind the men's field in terms of effectiveness.

\section{"I don't like a woman leading the match." (Soccer woman)}

In individual sports, women who are preparing for a coaching career are in a better position. In athletics and martial arts, there is a tendency for clubs to employ more and more women coaches, and even a federal captain to lead a women's field (e.g. boxing). This result is outstanding because boxing is considered to be one of the roughest sports and the women's sport was also the last of the martial arts to appear at the Olympics, yet this change in attitude is already a significant achievement. Although athletes in martial arts have reported being oppressed alongside men, this developmental process is showing a positive direction. The vision of women judges can be similarly characterized, although this is also due to the fact that the international federation has made it compulsory to employ women judges in competitions where women compete. In all cases, however, the proportions tilt the scales in favor of men.

\section{"It doesn't matter to me whether a woman or a man leads the match." (Boxing woman)}

Weightlifting and boxing are considered the most masculine of all sports. Within this, they think that weightlifting is not acceptable to either gender, their bodies are distorted, unhealthy, they reject people's participation in this sport. However, women athletes do not feel this resistance. They consider their sport to be tough, but so far there is no need for further education among female athletes. Referees opportunities are similarly open to women, but as coaches, participation is not yet typical. In many cases, weightlifting women come from weightlifting, where the presence of female coaches can be observed in the field, which is interesting because the possibilities are exhausted after a change of sport.

\section{"I've always had male coaches, and even my coach and my partner are in better harmony." (Weightlifting Woman)}

Feminine sports are in a special position. Except for figure skating, men's participation in rhythmic gymnastics and artificial swimming at the Olympic Games is not yet typical. They have already invaded this unknown area, but they are just spreading their wings. Male synchronized swimmers have been given the green light for world championships, and for the time being, the male discipline of rhythmic gymnastics is still struggling for recognition. Women's representatives of sports reject men's participation in the latter two sports. The referee, on the other hand, is open to men, yet it is not a typical career choice for athletes entering the sport. Mostly, male judges enter the profession from outside, without a sporting past. Interviews with female competitors, on the other hand, revealed that the presence of male judges is important in the sport, but not for coaches. 


\section{"A male coach is unthinkable in our sport." (Woman doing rhythmic gymnastics)}

Figure skating is the only sport in the history of the Winter Olympics that was originally considered more of a men's sport, but over the years the effects of the media and various fashion waves (clothing) have helped make this sport "change genders," and now specifically include in feminine sports (ADAMS, 2011). The process was also strongly influenced by the trend that the aesthetic quality of costumes is part of the performance and is taken into account by judges when scoring. The appearance of men in sequined, glittering dresses, all combined with the graceful soft movements of the sport - while the contestants raise their female partners or lead in ice dance like a traditional dance - has lent a feminine character to the sport (BÉKI, 2018). In figure skating, both genders have the opportunity to return to the sport at the end of their racing careers, and in figure skating, they appear fully accepted in not all sports roles. Overall, it is very variable the principles by which athletes accept the gender of judges and coaches in their own sport. In some places, there are contradictions (boxing) between the very masculine nature and the acceptance of women on the coaching court, and in others the opposite (handball). There are also sports in which the appearance of men as coaches is for the time being rejected (RG) and there are somewhere women (football). There are also sports where the presence of female coaches would be accepted (water polo, wrestling) but not a typical career choice for athletes who are aging in sports. However, the referee career can be considered acceptable to both sexes in all sports.

In the questionnaire research $(\mathrm{N}=240), 63.8 \%$ of female athletes have a high school degree, while $25.8 \%$ attended university or college. $62.9 \%$ of them are still studying, $21.3 \%$ are doing mental work, $5.8 \%$ are doing physical work. $77.5 \%$ are amateur and $22.5 \%$ are professional athletes. $46.7 \%$ of them participate in individual sports, while $53.3 \%$ participate in team sports. (Figure 1)

Figure 1. The distribution of the sample according to sports

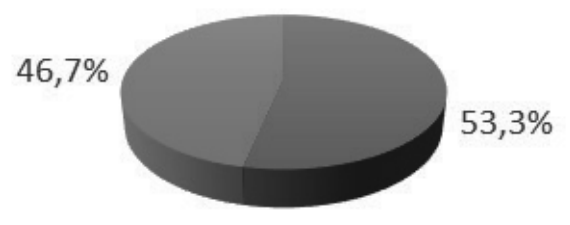

Source: own editing

In the field of studies, $46.3 \%$ of female athletes study higher education, $15.8 \%$ work, and no longer study, $11.7 \%$ study professionally, and $13.8 \%$ do not plan to continue their studies. In continuing education, commitment to the sport is strongly reflected among women athletes. $53.8 \%$ are continuing their studies in sports, $10.8 \%$ are unsure. (Figure 2)
Figure 2. The distribution of the sample according to they would studying in the sports-related field.

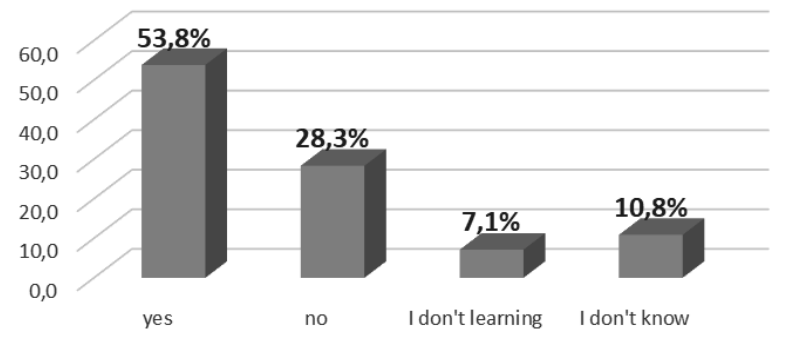

Source: own editing

Building a dual career, helping and supporting it, is significant support for the development of an athlete's career. Athletes were asked if they had a part in it if they had come across such a program, help during their career. $51.6 \%$ of women athletes have encountered a dual career program. (Figure 3)

Figure 3. The distribution of the sample according to they have met an athlete dual career program.

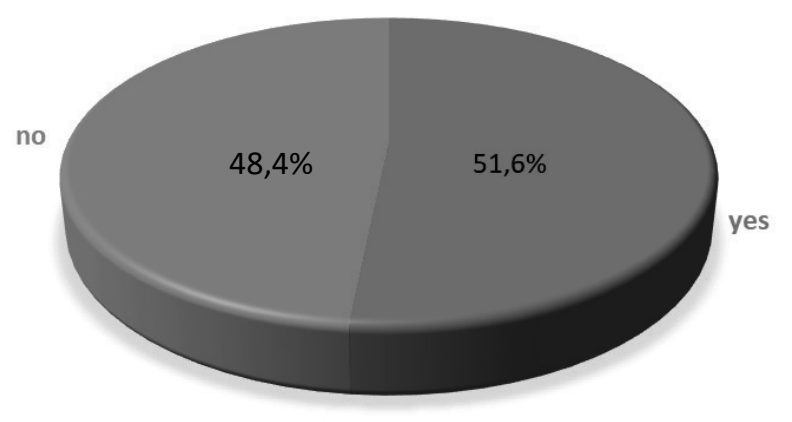

Source: own editing

The career-building awareness of women athletes was assessed by the following question, which examines preparation for the post-career life stage of athletes. Are athlete women preparing for post-sport careers? According to the answers, $35.1 \%$ of them are not preparing for the post-sports life stage, while the remaining $64.9 \%$ are taking it into account and preparing for a civilian career, $35.8 \%$ of them are preparing for the labor market with their studies. (Figure 4)

Figure 4. The distribution of the sample according to preparing for a post-competitive career.

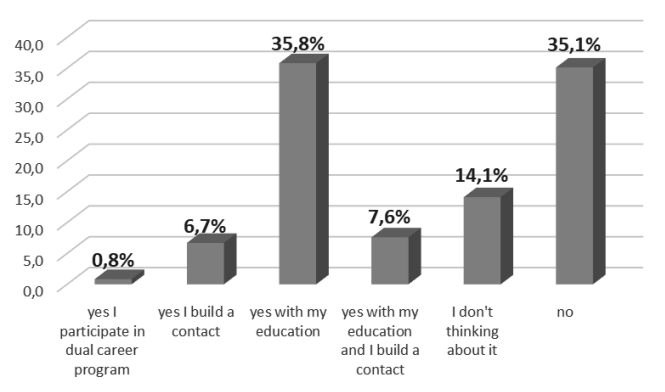

Source: own editing 
As the main topic of the research on the issue of staying in sports, $43.8 \%$ of athletes fully agree that they want to stay in sports after their athletic career. $9.6 \%$ of female athletes do not want to stay in sports, the other results indicate the degree of staying in sports. (Figure 5)

Figure 5. The distribution of the sample according to agree with: I want to stay in sports (coach, sports official, etc.).

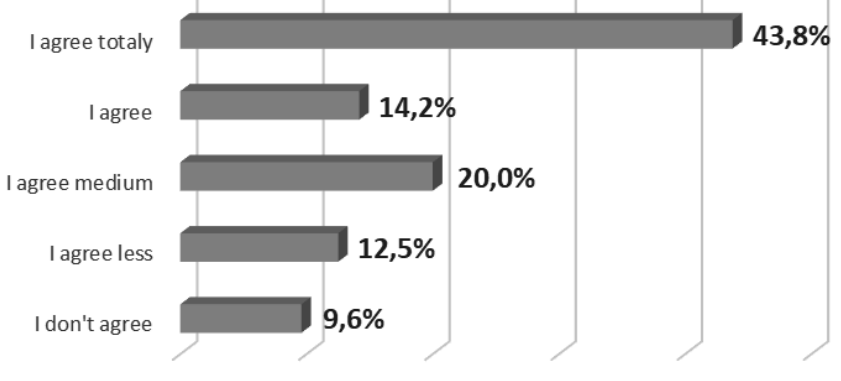

Source: own editing

Athlete identity emerges strongly in terms of career. Female athletes want to study and work in a sport-related field. The result serves as a guideline for education and the labor market. Sports science training and job creation in sport provide perspective for female athletes in their civil careers. Athlete socialization has a strong impact on many areas of social subsystems. In our research, it has become apparent that athletes are consciously prepared, they would be prepared for the post-career life stage of athletes, but less support for dual careers appears to them. Sport offers an opportunity to learn in job creation for those who have been raised in sport.

\section{DISCUSSION}

Time spent in sports can have an impact on public perception. Just think that masculine sports that have long accommodated female participants will become more accepted year after year. An example is a process that can be observed in martial arts at the Olympics. Sports that have already joined the Olympic program as bisexuals, such as taekwondo, have been categorized as gender-neutral in my research, and female participants are not judged on the basis of stereotypes. In the case of boxing, on the other hand, where women are the last in the grip, after all, martial arts, spectators and sports leaders still have to get used to the presence and competition of female competitors. Of course, the same principle is true in the field of women's sports, as no one questions the participation of men in figure skating (although it is a fact that it is a so-called "non-changing" sport), but the presence of male athletes is still unusual and not yet at the Olympic Games. Athletes 'perceptions seem to be similarly important, as later on, their own experiences will determine how they view women's and men's disciplines in different sports. While the presence of male coaches is accepted in addition to the female major of a masculine sport, it is currently inconceivable for a female coach to appear at the head of a male major in the same sport. Even at the club level, one such phenomenon may occur in individual sports, but at a higher level it is ruled out for the time being. Thus, in this area, women are left with inferiority and future changes will show change if it materializes. The results show that even in today's sports, former athletes, especially in coaching roles, run into a glass ceiling when it comes to advancing. In our view, sports are moving in the direction of becoming bisexual or neutral. However, it is undeniable that gender stereotypes about sports can influence the changing trends of sports, including career opportunities, for some time to come. Hypotheses proved to be true in some sports and false in others. The assumption that female athletes in male and male athletes do not have the opportunity to return to other sports roles (coach, referee) in football and hockey at the end of their athletic careers has been clearly confirmed. In individual sports, however, he leaned in all cases. Although coaching careers have been pushed back more than the judiciary, for the time being, there is still a steady improving trend. Female athletes have a strong athlete identity. Sport plays a central role in their careers, and they envision their studies and civic careers in the sport if they are given the opportunity to do so. Sports science studies are not gender-specific, but their position in the labor market is influenced by their gender.

The interview research also revealed that athletes are more accepting of coaches of the opposite sex in masculine sports, while men do not appear as coaches in feminine sports, but referee careers have long been open to them. Their own career opportunities, however, include coaching roles despite the rejection of female coaches in men's sports. An exception to this is boxing, where the recognition of the female federal captain is becoming more and more accepted, so the opportunities for club coaches are also increasing.

The topic will be closed with the lines of Ágota Budaváry, namely, in whose opinion the coaching training is waiting to be solved. It needed excellent professionals to educate an excellent athlete and you will be able to get involved in gender issues. In other words, Hungary must pay attention to the voice of women in sports, coaching, and in all areas where the members of the "weaker sex" have not been able to or are no longer trying to enter. In Hungary, this takes place at a very low volume. With us, everything turns out to be delayed, people, but especially women, simply do not dare to talk openly about it. In contrast, at the opening of the Cannes Film Festival, one of the speeches began with "Mesdames, Mesdames, Mesdames et Messieurs..." and went on to say that Harvey Weinstein will have no playing field here. That is, they constantly remember that yes, women need to be protected and stand up for their rights. And Hungary seems to have forgotten about the blatant abuses perpetrated by our excellence, which is already a great oeuvre, whether in theater or sports. Their victims received very little attention."

(BUDAVÁRY, 2018) 


\section{REFERENCES}

Abele A. E. (2000): A Dual-Impact Model of Gender and Carrier-Related Processes. In: Eckes, T. Trauthner H. M. (szerk.): The Developmental Social Psychology of Gender. LEA

Adams M. L. (2011): Artistic Impressions: Figure Skating, Masculinity, and the Limits of Sport. University of Toronto Press, London, Canada.

Andorka R. (2006): Bevezetés a szociológiába, Budapest, Osiris Kiadó.

András K, Havran Zs. (2017): New business strategies on football clubs. Apstract - Applied studies in agribusiness and commerce 9. 1-2. 67-74.

Bácsné Bába É., Balogh R., Bács B., Molnár A., Fenyves V., Müller A. (2019): A passzív sportfogyasztás motivációinak vizsgálata a nemek tükrében.Economica. Új évf. 10 (1), 1-6

Béki P. (2015): Masculine brave in the feminine winter sports. Apstract - Applied studies in agribusiness and commerce 9:. 1-2. 81-85.

Béki P. (2017): Sztereotípiák a sportban, avagy a női sport létjogosultsága napjaink magyar társadalmában. Acta academiae paedagogicae agriensis nova series: sectio sport 44. 171-189.

Béki P. Géczi G. (2017): Women on ice - gender equalization. Apstract - Applied studies in agribusiness and commerce 11.1-2. 137-145.

Béki P. (2018): Multidimenzionális nemi sztereotípiák a 21. század versenysportjában Magyarországon. PhD értekezés, Testnevelési Egyetem. Budapest

Belinszki E. (2003). A társadalmi nem, mint a kutatás tárgya. Szociológiai szemle. 2003/1. pp: 169-172. Magyar Szociológiai Társaság. Budapest. Bodnár, I. Perényi, Sz. (2016). Értékháló az iskolai testnevelés körül. In Kovács, K. (szerk.) Értékteremtô Testnevelés. Debreceni Egyetemi Kiadó. Debrecen. 101-110.

Bodnár I. (2003): Társadalmi diskurzus a női sportról a múlt század első felében. In Földesiné Szabó, Gy. Gál, A. (szerk.): Sport és társadalom, Budapest, Magyar Sporttudományi Szemle, 116-133. oldal.

Bodnár I. (2012): Az edzői munka, mint nôi foglalkozási életpálya. Phd disszertáció Semmelweis Egyetem, Budapest

Bordás S. Mező V. Kontó G. (2010): Pályakövetés 2010. A Kodolányi János Főiskola végzett hallgatóinak pályakövetési vizsgálata. Székesfehérvár, Kodolányi János Fóiskola. Forrás: http://karrier. kodolanyi.hu/banner/palyakovetes2010.pdf, letöltés: 2018.02.01.
Buda B. (1998): A nemi szerepek problémája. In: Erôs, F. (szerk.): Megismerés, elôítélet, identitás. Új mandátum könyvkiadó, Budapest Dabasi Halász, Zs. (2011): Munkaerőpiac és foglalkoztatáspolitika. Miskolci Egyetemi kiadó, Miskolc.

Deloitte (2015): A frissdiplomásoknak már nem a magas bér a legvonzóbb. Forrás: http://www2.deloitte.com/hu/hu/pages/ karrier/articles/first-stepssajto-2015.html. Letöltés: 2018.01.05 Eitzen D. S. (1996): Classism in sport: the powerless bear the burden. Jornal of Sport and Social Issue 20.. 1 95-105. DOI $10.1177 / 019372396020001008$

Faragó B. (2015): Élsportolók életpálya modelljei. Campus Kiadó, Budapest.

Faragó B. (2017): A sport társadalmi hasznosulása Győr vállalatai körében. In: Keresztes G.(szerk): Nemzetközi Multidiszciplináris Konferencia, [Spring Wind Conference. International Multidisciplinary Conference] 208-2016.

Faragó B. Béki P. Konczosné Szombathelyi M. (2018): Correlation between athletic and workplace career in the competency matrix. In: Karlovitz János Tibor (szerk.): Some Recent Research from Economics and Business Studies. Komárno: International Research Institute, 2018. pp. 73-80.

Faragó B., Konczosné Szombathelyi M. (2017): Social evaluation of sport on the way of local development. In: Bukor J., Korcsmáros E. (szerk.): A Selye János Egyetem 2017-es "Érték, minőség és versenyképesség - a 21. század kihívásai" [Value, Quality and Competitiveness - Challenges of the 21st Century] Zborník medzinárodnej vedeckej konferencie Univerzity J. Selyeho pp. 75-85.

Farkas J. (2012): Az Európai Unió sport szakpolitikája, fốbb dokumentumai és ezek hazai implementációjának elemzése. Szakdolgozat. Pázmány Péter Katolikus Egyetem, Jog- és Államtudományi Kar, Budapest.

Farkas J. Jókai M. Kozsla T. (2017): A sportolói kettős karrier fejlesztési lehetőségeinek vizsgálata Magyarországon. ST/PSS 2. 1-2. 81-88. DOI: 10.21846/TST.2017.1-2.14

Fekete É. Siposné Nádori E. (2013): A társadalom térszerkezete. Building Partnership, Miskolc

Gál A. Farkas P. (2017): Kétséges nem - kétséges fair play. In: Vermes K, Farkas P (szerk.) A fair play ereje?! Tények és értékek a 21. századi sport világában. Budapest: Testnevelési Egyetem, 82-91.

GfK Hungária Piackutató Intézetet (2015): Provident Családi Kassza Index 2015. Forrás: https://www.provident. hu/kapcsolat/sajtoszoba/provident-csaladikassza-index-2015. Letöltés: 2018.01.15. 
Gombocz J. Gombocz G. (2006): Utánpótlás korú sportolók véleménye edzőjükről. (Az ideális és a reális edzőképe 14-16 éves kosárlabdázó fiúk ítéletében). Kalokagathia, 1-2. 76-85. Gombocz J. (1998): A sportoló szocializációja és nevelése. Kalokagathia, TE, Budapest

Gősi Zs. Sallói I. (2017): Rögös út a sportkarrier: A fiatal magyar labdarúgók karrier esélyei. Magyar Sporttudományi Szemle, 72. 11-19.

Gôsi Zs. (2017): A sportszövetségek bevételi szerkezetének és vagyonának változása 2011 és 2015 között. In Szmodits, M. Szôts, G. (szerk.). Sportirányítás gazdasági kérdései Budapest. Magyar Sporttudományi Társaság. 91-108.

Hadas M. (1994): Himnem-nönem. In: Hadas M. (szerk): Férfiuralorn.' írásokk nőkről, ferfiakról, ferninizrnusról. Replika Kör. Budapest:. 246-264.

Héra G. Ligeti Gy. (2005): Módszertan. Bevezetés a társadalmi jelenségek kutatásába. Osiris, Budapest.

Kerbeth L. K. (1988): Separate Spheres, Female Worlds, Woman's Place: The Rhetoric of Women's History. The Journal of American History, 5. 75/1 Organization of American Historians, 9-39

Kiss A. (2017): Kettős karrier: élet a sport után. Magyar Sporttudományi Szemle

Lenskyj J. H. (2012): “The Olympic Industry and Women: An Alternative Perspective. The Palgrave Handbook of Olympic Studies. $430-442$

Lenskyj J. H.(2005): Out on the Field: Gender, Sport and Sexualities. Women's Press, Toronto

Nagy B. (1993): Nõk a vezetésben. Szociológiai Szemle 1993/3-4. Budapest, pp. 147-166.

Neményi M. (1994): „Miért nincs Magyarországon nőmozgalom?" in Hadas Miklós szerk. Férfiuralom. Budapest, Replika Kör, 235.

Neményi M., Tóth O. (1998): A nők társadalmi szerepének változásai az ezredfordulón. Nemzeti Stratégiai Kutatások. Budapest: MTA. 60.Metheny, E. (1965). Symbolic forms of movement: the feminine image in sports. In Metheny, E. (szerk.), Connotations of movement in sport and dance Dubuque: Brown.43-56.

Murphy G. M., Petitpas A.J., Brewer B. W. (1996). Identity froclosure, athletic identity and career maturiti in intercollegiate athletes. The Sport Psyhologist. 10. 239-246. Neményi M. (1994): „Miért nincs Magyarországon nómozgalom?" In: Hadas Miklós (szerk.) Férfiuralom. Budapest, Replika Kör, 215-225.
Offen K. M. (2000): European Feminisms, 1700-1950: A Political History. Stanford University Press.

Páthy Á. Tömböly, T. (2010): A Széchenyi István Egyetem 2010-es hallgatói motivációs vizsgálata. DPR Füzetek I. Győr: Széchenyi István

Petô A. (2017): Revisionist histories, 'future memories'. European politics and society 18: 1. 41-51.

Rámháp Sz. (2017): Felsőoktatási továbbtanulási motivációk Magyarországon a változó ifjúság és a piacosodó felsőoktatás tükrében. PhD Disszertáció, Győr. Széchenyi István Egyetem.

Rámháp Sz., Nagy D., Országh Á., Rechnitzer J., Filep B. (2017): Career choice motivation of high school students in context with hanging higher education in knowledge economy. Poslovna Izvrsnost / Business Excellence. 11. 2. 23-37.

Ráthonyi-Ódor K., Molnár G., Borbély A. (2013): Responsible behavior or business?: Social Responsibility (CSR) in Sport Management, Apstract - Applied studies in agribusiness and commerce 7: (1-2). 80-93.

Révész L., Bognár J., Csáki I., Trzaskoma-Bicsérdy G. (2013): Az edzô-sportoló kapcsolat vizsgálata az úszás sportágban. Magyar pedagógia. 113. 1. 53-72.

Révész L., Bognár J., Géczi G. (2007): Kiválasztás, tehetség és pedagógiai értékek az úszásban. Új Pedagógiai Szemle. 4. $45-53$.

Showalter E. (1989) (szerk.): Speaking of Gender. London: Routledge, Chapman and Hall

Simon A. (2018): „Befogja a száját, és mindent elvisel”. Interjú Budavári Ágotával, a Sportkórház sportpszichológusával INTERJÚ - LXII. évfolyam, 25. szám, 2018. június 22. Simon, A. (2018): „Befogja a száját, és mindent elvisel”. Interjú Budavári Ágotával, a Sportkórház sportpszichológusával interjú 62. 25.

Somlai P.(1997): Szocializáció. Corvina, Budapest

Somlai P. (2010): Változó ifjúság. Educatio. 2. 175-190.

Sterbenz T., Gulyás E., Kovács E., Zilinyi Zs. (2017): Kettôs karrier és sportági részvétel a kosárlabdázásban. Kettős karrier a sportban szatellit konferencia. Magyar Sporttudományi Társaság. Pécs. 2017. június 1-2. mstt.hu/ wpcontent/uploads/MSTT_Szemle2017_DC4AC. Letöltés: 2018.03.06.

Struna N. (1985):"In Glorious Disarray: The Literature of American Sport History," Research Quarterly for Exercise and Sport, 56, 2, pp. 151-160. 
Szakály Zs., Ihász F., Király T., Murai B., Konczos Cs. (2003): Testalkat, testösszetétel és az aerob teljesítmény hosszmetszeti vizsgálatának tapasztalatai női fóiskolai hallgatóknál: Observations of the Longitudinal Section Examination of the Physique,Body Composition and Aerobic Performance in College Female Students. Magyar Sporttudományi Szemle 4: 1 pp. 30-32., 3 p. (2003)

Vertinsky P. (1983): Gender Relations, Women's History and Sport History: A Decade of Changing Enquiry, 1983-93, Journal of Sport History 21. pp. 1-24.

Walby S. (1996): Comparative analysis of gender relations in employment in Western Europe. In: Women in Management Review. 11, 5, pp. 9-16. 
